\title{
Socio-Economic Profile of Pulikulam Cattle Rearers in Madurai and Sivagangai Districts of Tamil Nadu, India
}

\author{
S. Thesinguraja ${ }^{1 *}$, P. Mathialagan ${ }^{1}$, P. Thilakar ${ }^{1}$, P. Devendran ${ }^{2}$ and V. Palanichamy ${ }^{3}$ \\ ${ }^{1}$ Department of Veterinary and Animal Husbandry Extension Education, Madras Veterinary \\ College, Vepery, Chennai - 600 007, Tamil Nadu, India \\ ${ }^{2}$ Post Graduate Research Institute in Animal Sciences (PGRIAS), Kattupakkam, \\ Kancheepuram - 603 203, Tamil Nadu, India \\ ${ }^{3}$ Veterinary University Training and Diagnostic Centre, Thiyagarajar Engineering College Road, \\ Thirupparankundram, Madurai-625 005, Tamil Nadu, India \\ *Corresponding author
}

A B S T R A C T

\begin{tabular}{|c|}
\hline Keywords \\
\hline $\begin{array}{l}\text { Pulikulam cattle } \\
\text { rearers, Socio- } \\
\text { economic profile } \\
\text { and zero input. }\end{array}$ \\
\hline Article Info \\
\hline $\begin{array}{l}\text { Accepted: } \\
07 \text { October } 2017 \\
\text { Available Online: } \\
10 \text { December } 2017\end{array}$ \\
\hline
\end{tabular}

\section{Introduction}

The livestock sector plays an important role in the socio-economic development of rural households in India. It contributes about three per cent to the nation's GDP and 30 per cent to the agricultural GDP (Anonymous, 2015). India has 40 registered indigenous cattle breeds. Tamil Nadu has only four registered indigenous cattle namely Bargur, Kangayam, Umblachery, Pulikulam. Among this breeds
Pulikulam cattle was reared as migratory herd with herd size of about 150-400 animals. Farmers are benefited through penning which provides rich organic manure for agricultural crops, (Vivekanandan and Alagumalai, 2013). The population of Pulikulam cattle was about 50,000 , of which 20,000 were breeding females. These animals are distributed in more than 200 herds of about 50 villages of 
Madurai, Virudhunagar and Sivagangai districts of Tamil Nadu (Kanakraj and Kathiresan, 2006). The number of herds per village varied from 1 to 24 . The herd size of the Pulikulam cattle varied from 30 to 500 with an average of 225 , which was reported to be decreasing during last $2-3$ decades mainly due to shrinkage in grazing land (Singh et al., 2012).

\section{Materials and Methods}

Madurai and Sivagangai districts were purposively selected for this study due to the presence of high Pulikulam cattle population in Tamil Nadu (Madurai and Sivagangai districts had fairly a good population of Pulikulam cattle $(21,225)$ survey report on Pulikulam cattle, SEVA, 2012). Usilampatti and Thiruparankundram blocks were selected purposively from Madurai and similarly, Sivagangai and Manamadurai block of Sivagangai districts as it contains fairly a good population of Pulikulam cattle. Three villages viz., U. Vadipatti, Idayapatti and Chettiyapatti in Usilampatti block (24 Pulikulam cattle rearers) were selected and three village viz., Manapatti, Thenpalanji and Vadapalanji in Thiruparankundram block (21 Pulikulam cattle rearers) were selected. Similarly two villages viz., Kilathiri and Kuranthaikulam in Sivagangai block (25 Pulikulam cattle rearers) and two villages viz., Manangkathan and Valarenthal (20 Pulikulam cattle rearers) were selected.

These villages were selected based on proportionate stratified random sampling technique as they have considerable population of Pulikulam cattle. A wellstructured pre-tested interview schedule was developed for collecting data from the respondents according to the objectives of the study. The primary data was collected from the respondents by conducting personal interview.

\section{Results and Discussion}

The result of the investigation carried out was presented through the Table 1 showing the socio-economic profile of Pulikulam cattle rearers.

\section{Land holding}

Table 1 indicates that above one-half (55.56 per cent) of the respondents were landless farmers and they reared their cattle in freerange community rearing system. This was followed by 37.78 per cent of the respondents were marginal farmers.

This might be due to the fact that rearers in the study area migrate throughout the year in surrounding districts for grazing the cattle. The results of the present land holding differ with the findings of Ghotge and Gaspardy (2016) who reported that the average land holding was 4.05 acres.

\section{Age}

Table 1 clearly depicts that 42.22 percent of the respondents belonged to old age at the time of enquiry. This was in agreement with Mali et al., (2014) and Thombre et al., (2015) who reported that most of the respondents belonged to old age category.

\section{Community}

Table 1 depicts that 84.44 percent of the respondents belonged to $\mathrm{BC}$ community followed by MBC community (14.00 per cent).

This might be due to fact that most of the BC community farmers rear Pulikulam cattle as their ancestral occupation. Most interesting fact in this finding was that none of the respondent belonged to $\mathrm{OC}, \mathrm{SC}$ and $\mathrm{ST}$ categories. 


\section{Education}

Table 1 indicates that one fourth of the respondents (40.00 per cent) educated up to primary level of education followed by 32.22 per cent were illiterate. This might be due to the fact that the respondents followed ancestor's occupation early in life due to their poor economic status.

\section{Family type}

It could be found from Table 1 that majority (87.78 per cent) of the respondents belonged to joint family whereas, 12.22 percent of the respondents belonged to nuclear family. This was mainly due to fact that most of respondents live in close community system where they follow their tradition and culture set by their ancestors

\section{Herd size for Semi-intensive system of rearing the Pulikulam cattle}

Table 1 reveals that there were cent percent of the respondents who reared their cattle by semi-intensive system of rearing has small herd size. This might be due to fact that most of the rearers reared their cattle for Jallikattu, ploughing and carting in small numbers for providing better training to the cattle.

\section{Herd size for free range system of rearing Pulikulam cattle}

Table 1 reveals that majority (78.08 per cent) of the respondents belonged to medium (100 - 200 numbers) herd size category, followed by 21.92 per cent of the respondents belonged to high (more than 200 numbers) herd size category.

\section{Main occupation}

A majority ( 82.22 per cent) of the respondents had Animal Husbandry as main occupation, followed by agriculture (10.00 per cent), private job (6.67 per cent) and government job (1.11 per cent). This might be due to fact that rearing Pulikulam cattle would improve their livelihood. The results of the present occupational status differ with the findings of Kishore et al., (2013) who reported that majority of respondents maintained agriculture as the main occupation.

\section{Total annual income}

It could be observed from the Table 1 that maximum proportion (76.67 per cent) of the total respondents had total annual income as eighty thousand to one lakh sixty five thousand. This is in agreement with the findings of Verma et al., (2014) who reported that most of the respondents belonged to medium income category having an annual income between Rs. 80,000 - 1, 30,000.

\section{Annual dairy income}

Table 1 indicates that maximum proportion 94.44 per cent of the total respondents had eighty thousand to one lakh twenty thousand annual dairy income. This finding was not in consonance with result of Sathyanarayan et al., (2010) who reported that most of the respondents were belonged to low income category.

\section{Experience in dairy farming}

As shown in the Table 1 nearly one fifth (56.67 per cent) of the respondents had high level (above 20 years) of experience in Pulikulam cattle rearing. This might be due to the fact that most of respondents were old age category and preferred rearing Pulikulam cattle early in life for their livelihood. This was in agreement with Kumar and Tripathi (2012) who reported that most of the respondents had 10- 25 years of experience in livestock farming. 
Table.1 Socio-economic profile of Pulikulam cattle rearers

$(\mathrm{N}=90)$

\begin{tabular}{|c|c|c|c|}
\hline Variables & Category & Frequency & Percentage \\
\hline \multirow[t]{3}{*}{ Age } & Young $(<35$ years $)$ & 31 & 34.44 \\
\hline & Middle ( $36-45$ years) & 21 & 23.33 \\
\hline & Old $(>45$ years $)$ & 38 & 42.22 \\
\hline \multirow[t]{2}{*}{ Community } & $\mathrm{BC}$ & 76 & 84.44 \\
\hline & MBC & 14 & 15.56 \\
\hline \multirow[t]{5}{*}{ Education } & Illiterate & 29 & 32.22 \\
\hline & Primary & 36 & 40.00 \\
\hline & Middle & 20 & 22.22 \\
\hline & Secondary & 2 & 02.22 \\
\hline & Higher secondary & 3 & 03.33 \\
\hline \multirow[t]{2}{*}{ Family type } & Nuclear & 11 & 12.22 \\
\hline & Joint & 79 & 87.78 \\
\hline \multirow[t]{3}{*}{ Annual total income } & $<80000$ & 6 & 06.67 \\
\hline & $80001-165000$ & 16 & 17.78 \\
\hline & $>165000$ & 68 & 75.56 \\
\hline \multirow[t]{4}{*}{ Land holding (in acres) } & Landless & 50 & 55.56 \\
\hline & Marginal (up to 2.5) & 34 & 37.78 \\
\hline & Small $(2.6-5.0)$ & 6 & 06.67 \\
\hline & Large (above 5.00) & -- & -- \\
\hline \multirow{3}{*}{$\begin{array}{l}\text { Herd size for semi intensive system } \\
\text { of rearing farmers }(\mathrm{N}=17)\end{array}$} & Small (up to 3 cattle) & 17 & 100.00 \\
\hline & Medium ( $4-6$ cattle) & -- & -- \\
\hline & Large (above 6 cattle) & -- & -- \\
\hline \multirow{3}{*}{$\begin{array}{l}\text { Herd size for free range system of } \\
\text { rearing farmers }(\mathrm{N}=73)\end{array}$} & Small $(<100)$ & -- & -- \\
\hline & Medium $(100-200)$ & 57 & 78.08 \\
\hline & Large $(>200)$ & 16 & 21.92 \\
\hline \multirow[t]{3}{*}{ Farm experience } & Low (up to $10 \mathrm{yrs}$ ) & 5 & 05.56 \\
\hline & Medium (10-20yrs) & 34 & 37.78 \\
\hline & High (Above 20yrs) & 51 & 56.67 \\
\hline \multirow[t]{3}{*}{ Contact with extension agency } & Low & 25 & 27.78 \\
\hline & Medium & 46 & 51.11 \\
\hline & High & 19 & 21.11 \\
\hline \multirow[t]{3}{*}{ Social participation } & Low & 33 & 36.67 \\
\hline & Medium & 33 & 36.67 \\
\hline & High & 24 & 26.67 \\
\hline \multirow[t]{3}{*}{ Mass media exposure } & Low & 51 & 56.67 \\
\hline & Medium & 14 & 15.56 \\
\hline & High & 25 & 27.78 \\
\hline \multirow[t]{3}{*}{ Economic motivation } & Low & -- & -- \\
\hline & Medium & 38 & 42.22 \\
\hline & High & 52 & 57.78 \\
\hline
\end{tabular}




\section{Contact with extension agency}

It could be seen from Table 1 that one half (51.11 per cent) of the respondents had medium level of contact with extension agency, followed by low (27.78 per cent) and high (21.11 per cent) level of contact with extension agency. Farmers were found to contact extension personnel for guidance and advice regarding getting subsidies and government schemes. This was in agreement with Ashwar et al., (2011) and Sabale et al., (2014) who reported that most of the respondents had medium level of extension agency contact.

\section{Social participation}

Table 1 indicates that equal percent (36.67 per cent) of respondents had medium and low level of social participation. This was in agreement with Subrahmanyeswari et al., (2007) who reported that most of the respondents had medium level of social participation.

\section{Mass media exposure}

Table 1 reveals that 56.67 per cent of the respondents had low level of mass media exposure followed by high ( 27.78 per cent) and medium (15.56 per cent) level of mass media exposure. This might be due to fact that most of rearers stay away from residency along with herd in cultivable land. This was in agreement with Devaki et al., (2015) who reported that most of the respondents had low level of mass media exposure.

\section{Economic motivation}

A majority (57.78 per cent) of the respondents had high level of economic motivation while 42.22 per cent belonged to medium level of economic motivation. This indicates that Pulikulam cattle rearers preferred more production and to earn more income for higher living standard. This was in agreement with Gour (2002) and Mali et al., (2014) who reported that most of the respondents had high level of economic motivation.

The profile characteristic like age, education, experience, herd size, occupation and extension agency contact help us to identify the socio-economic status. Keeping this as base they should be given capacity building and need based training programmes by government and non-government extension agencies. The finding of the study further implied that subject to the availability of drinking water and grazing land Pulikulam cattle rearing with zero input and management may be advocated among farmers for better income.

\section{References}

Anonymous, 2015. Basic Animal Husbandry and Fisheries Statistics, Government of India, Ministry of Agriculture \& Farmers Welfare Department of Animal Husbandry, Dairying And Fisheries, Krishi Bhawan, New Delhi.

Ashwar, B. K., J. Ninan, and M.C. Soni, 2011. Characteristics of dairy farmers of North Gujarat. Indian J. Field Vet., 7(2): 57-62.

Devaki, K., K. Senthilkumar, and R. Subramanian, 2015. Socio-economic profile of livestock farm women of Thiruvallur district, Tamil Nadu. International Journal of Science, Environment and Technology, 4(5): 1322-1329.

Ghotge, N., and A. Gáspárdy 2016. A socioeconomic pilot study on Indian periurban dairy production. Int $J$ Agricultural Sci Food Technology, 2(1): 28-34.

Gour, A.K. 2002. Factors influencing adoption of some improved animal 
husbandry practices of dairying in Anand and Vadodara districts of Gujarat. Ph.D. Thesis, Gujarat Agricultural University, S.K. Nagar.

Kanakraj, P and D. Kathiresan, 2006. Study on the physical and productive characteristics of Pulikulam breed of cattle and Katchaikatty sheep. Final Report of the project submitted to SEVA, Madurai.

Kishore, K., M. Mahender, and C. Harikrishna, 2013. A study on buffalo management practices in Khammam district of Andhra Pradesh. Buffalo Bulletin, 32(2): 54-56.

Kumar, R., and H. Tripathi, 2012. Impact of cattle development on socio-economic profile of dairy farmers. Indian Vet. J., 89(10): 36-38.

Mali, K. N., R. B. Belli, and M. G. Kitturmath, 2014. Study of the socioeconomic characteristics of dairy and non-dairy farmers. Agriculture Update, 9(1): 54-58.

Sabale, A. N., D.D. Suradkar, B.M. Thombre, 2014. Entrepreneurial behaviour of farmers in Marathwada region. Agriculture update, 9(1): 25-30.
Sathyanarayan, K., V. Jagadeeswary, V. C. Murthy, S.W. Ruban, G. Sudha, 2010. Socio-economic status of livestock farmers of Narasapura village-a benchmark analysis. Veterinary World, 3(5):215-218.

Singh, P.K., R.K. Pundir, P. Kumarasamy and P. Vivekanandan, 2013. Management and physical features of migratory Pulikulam cattle of Tamil Nadu. Indian. J. of Anim. Sci., 82 (12): 1587-1590.

Subrahmanyeswari, B., K.V. Reddy, B.S. Rao, 2007. Entrepreneurial behavior of rural women farmers in dairying: a multidimensional analysis. Livestock Research for Rural Development, 19(1): 2.

Thombre, B. M., D. D. Suradkar, andJ. M. Deshmukh, 2015. Adoption of cattle rearing practices by Red Kandhari cattle owners. Indian Journal of Animal Research, 49(5): 731-735.

Verma, A. K., L. Niranjan, S. R. Avhad, and Hari, R. 2014. Socio-economic status of farmers rearing Kherigarh, an indigenous breed of cattle. Asian Journal of Animal Science, 9(2): 134137.

\section{How to cite this article:}

Thesinguraja S., P. Mathialagan, P. Thilakar, P. Devendran and Palanichamy V. 2017. SocioEconomic Profile of Pulikulam Cattle Rearers in Madurai and Sivagangai Districts of Tamil Nadu, India. Int.J.Curr.Microbiol.App.Sci. 6(12): 424-429. doi: https://doi.org/10.20546/ijcmas.2017.612.051 